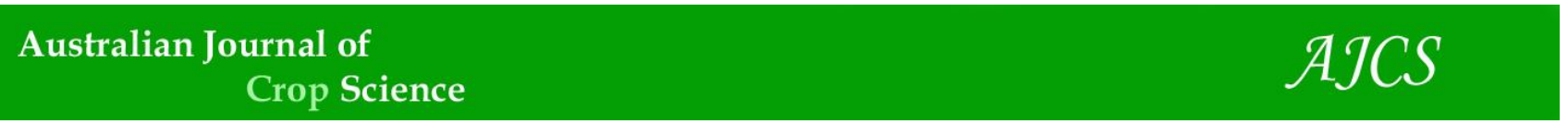

AJCS 14(09):1355-1361 (2020)

ISSN:1835-2707

doi: 10.21475/ajcs.20.14.09.p1844

\title{
Late nitrogen topdressing increases nutritional and industrial quality of white oat (Avena sativa) grain
}

\author{
Julhana Cristina Sponchiado, Clovis Arruda Souza*, Luis Sangoi, Cileide Maria Medeiros Coelho, Deivid \\ Luis Vieira Stefen
}

\author{
Department of Agronomy, Laboratory of Crop Science, Santa Catarina State University (UDESC), ZIP code \\ 88.520.000, Lages, Santa Catarina, Brazil
}

*Corresponding author: souza_clovis@yahoo.com.br

\begin{abstract}
Nitrogen is a nutrient that most limits the development, biomass yield and protein composition of Poaceae. The $\mathrm{N}$ losses can be reduced by synchronizing fertilizer additions with plant uptake requirements. The objective of this study was to investigate the effect of $\mathrm{N}$ topdressing at different rates and times on grain yield and industrial quality of two white oat cultivars. The experiment was carried out under field conditions, from July to November of 2014, in a factorial design $2 \times 3 \times 4$, with four replications. Two oat cultivars (URS Guria and URS Brava) combined with nitrogen topdressing were applied under three management systems: (i) semilate, (ii) late and (iii) semi-late plus late, described as a growth stages (GS) GS31 (first node visible) and GS45 (booting) or split N on GS31 plus GS45 and N rates $\left(0,30,60\right.$ and $\left.90 \mathrm{~kg} \mathrm{ha}^{-1}\right)$ with urea as a source. White oat cultivars responded differently to nitrogen fertilization. The URS Brava cultivar showed higher hectoliter weight (HW) and crude protein in the grains (CP) and URS Guria higher number of spikelets per panicle (NSP) and plant lodging (LOD). Application of at least part of the $\mathrm{N}$ at the first detectable node played important role on grain yield and yield components. Splitting $\mathrm{N}$ fertilization in two applications, 50\% at the beginning of stem elongation and $50 \%$ at booting, favored higher yield and protein content of the grains. The increase in $\mathrm{N}$ rates up to $90 \mathrm{~kg}$ $\mathrm{ha}^{-1}$ did not promote grain yield, but it provided increases in grain thickness and protein content in white oats cultivars, increasing the nutritional (more protein), industrial quality (more flakes per ton of the grains) and grain yield leading to more profit to farmer.
\end{abstract}

Keywords: Avena sativa, Grain yield, Protein, N sidedressing, Grain Sieve.

Abbreviations: ANOVA_analyses of variance, GS_growth stages, N_nitrogen, OM_organic matter, SOV_source of variation.

\section{Introduction}

Oats are grown in the South, Southeast and Midwest regions of Brazil (CONAB, 2019). They are important winter species, mainly to produce grains and dry mass, favoring the notillage system (Webster and Wood, 2011). Oats grains are intended either for human consumption (and for such purpose, they are a functional food) or as animal feed, provided in rations or mixed with hay, silage and fodder (Oliveira et al., 2011). Agricultural research has sought for oats genotypes with high potential for grain production and technological standard highly tuned to the requirements by the flakes industry (Hartwig et al., 2007). Nitrogen (N) is the nutrient that most limits the development, biomass yield and protein composition of Poaceae (Jones et al., 2014). This limitation occurs because there is great demand for split application of this nutrient in synthetic form (Lin et al., 2013). $N$ is difficult to manage in tropical and subtropical regions, as a result of the large number of reactions and high instability in the soil (Ernani, 2016). The increase in the utilization of $\mathrm{N}$ can be obtained by split application in order to improve its efficiency (Ayadi et al., 2016). In white oats, split $\mathrm{N}$ application can increase the number of grains per panicle and the number of panicles per area. In order to favor the expression of yield components, Maral et al. (2013) suggested that $\mathrm{N}$ should be made available to white oats plants at sowing and at early tillering plant stage to stimulate tillering and to encourage panicle size preferably, when the plant has 5 to 6 leaves (early plant stem elongation). At such a moments, the plant responds with a large number of spikelets per panicle and consolidates the number of grains per panicle. A management strategy previously studied in other crops is $\mathrm{N}$ application at the reproductive stage of the crop, with the aim of increasing the grain quality. As $\mathrm{N}$ uptake depends on the growth rate of tissues, strategies to increase biomass before anthesis may represent a mechanism to increase the protein content of grains without restriction to grain yield (Finnan et al., 2019). Several studies have related $\mathrm{N}$ availability to increase protein and grain quality of wheat (Stefen et al., 2014; Rial-Lovera et al., 2016), maize (Nelson et al., 2009) and rice (Mingotte et al., 2015). For human diets, there is a preference for low-fat and protein-rich and fiber-rich grains, especially $\beta$-glucans related to reduction of cholesterol and blood sugar and weight loss (Hooda et al., 2010). Such an increase in protein content can be obtained by means of split topdressing application in later phenological stages of the crop. Research results about the effect of different $\mathrm{N}$ rates on grain yield 
and grain quality in white oat are inconsistent and there are few studies on semi-late (stem elongation stage) and late (booting stage) $\mathrm{N}$ application and their relationship with industrial quality. Thus, the objective of this work was to check the effect of different rates of semi-late and late topdressing nitrogen fertilization on production and industrial quality of grains in two white oats cultivars.

\section{Results}

\section{Plant morphology, grain yield and yield components}

The cultivars significantly $(P<0.05)$ affected the lodging index and number of spikelets per panicle. There were no differences for the plant height, grain yield and number of grains per spikelets (Supplementary Table 1). For stages of $\mathrm{N}$ application, there was a significant effect on most of the tested traits except for the number of grains per spikelet. The $\mathrm{N}$ rate did not affect the plant morphology, grain yield and yield components (Supplementary Table 1). In this study, the interaction of cultivar $x$ stage affected only on plant height and lodging, while the cultivar $\times$ rate interaction did not have significant effects. The cultivar $\times$ stage $\times$ rate interactions showed significant results on plant lodging (Supplementary Table 1). $\mathrm{N}$ rates and the interaction with cultivar and stage of $\mathrm{N}$ application were effective on a smaller number of traits, such as plant height and grain yield (Supplementary Table 1). In this way, it should be emphasized that these variables are dependent on the comparison between the two cultivars, stages and rates of topdressing $\mathrm{N}$ application. For plant height, the oat plants responded significantly to nitrogen fertilization in different stages (Table 2). The greater plant heights occurred, when $\mathrm{N}$ was applied at first node detectable stages and $\mathrm{N}$ split at first node detectable and booting (Table 2). The plant lodging, was observed at pre-harvest stage in both cultivars of white oat, but it was more pronounced in URS Guria, with $62 \%$ of lodging, while URS Brava had $41 \%$ (Table 3). The both cultivars showed greater plant height combined with its panicle weight (Table 3 ), because such treatments showed considerable plant height ( 1.20 and $1.22 \mathrm{~m}$ ) and grain yield $\left(3,111\right.$ and $3,222 \mathrm{~kg} \mathrm{ha}^{-1}$ for URS Guria and URS Brava, respectively) in response to $\mathrm{N}$ application (Table 3 ). The $\mathrm{N}$ application at booting stage resulted in plants with lower height and less lodging (Table 2). Also, in relation to lodging, differences were only found between $\mathrm{N}$ rates in URS Guria, with $\mathrm{N}$ fertilizer split in the first node detectable + booting, and URS Brava at all $\mathrm{N}$ on booting (Figure 1a). The responses to the rates were linear and distinct. The lodging pattern was inconsistent, whereas sometimes lodging was increased and sometimes decreased. This difference may be related to the proportions, in which lodging was occurred. In URS Guria, split $\mathrm{N}$ application split in the first node detectable + booting has led to an increase by $0.19 \%$ of lodging per $\mathrm{kg} \mathrm{ha}^{-1}$ of applied $\mathrm{N}$ because of the increased rate of $\mathrm{N}$ (Figure 1a). In contrast, in URS Brava, the application of increasing rates of $\mathrm{N}$, only at the booting stage, resulted in lower plant lodging (Table 2 and Figure 1a). The best results of oat grain yield were found with the application of $\mathrm{N}$ in first detectable stages and $\mathrm{N}$ split at first node detectable + booting, which resulted in 3,339 and 3,459 $\mathrm{kg} \mathrm{ha}^{-1}$ of grains, respectively (Table 2). Given the findings, $N$ application during the elongation of the first internode, either total or split, was fundamental for the expression of high grain yield in these cultivars, increasing grain production by $24 \%$, compared with the application only in the later booting stage (Table 2). This fact is possibly related to the greatest number of spikelets per panicle (Table 2), which is also observed in this study and discussed below. Grain yield of oats did not respond to different rates of topdressing nitrogen fertilization (Supplementary Table 1). This shows that the large part of the $\mathrm{N}$ extracted and used by the plant was possibly derived from the remains of the soybean crop and the mineralization of soil organic matter (Table $1, \mathrm{OM}=4.5 \%$ ). This value is medium to high. Under these conditions, lower $\mathrm{N}$ rates are sufficient to obtain satisfactory grain yield. Increasing the $\mathrm{N}$ rate did not have any effect on thousand-grain weight (Table 2). This fact may have occurred because of the higher number of grains per panicle (Table 2), which would increase the competition for photoassimilates in the panicle and consequently reduce the uniform mass of grains. The cultivar URS Guria had a higher number of spikelets per panicle than URS Brava (Supplementary Table 1). The adjustment of these components is directly linked to genetic control, which leads to a match between them depending on the treatment they receive. In relation to the stages, the application of all $\mathrm{N}$ topdressing on first detectable node stage or its $\mathrm{N}$ split at first detectable node + booting resulted in a greater number of spikelets per panicle (Table 2), emphasizing the importance of $\mathrm{N}$ availability in the initial stages, where the yield component is defined. The number of grains per spikelet was not influenced by the cultivars, $\mathrm{N}$ rates and neither by time of application of the fertilizer; the average value was 1.73 grains per spikelet (Supplementary Table 1).

\section{Grain quality}

There were no differences for thousand grain weight and percentage of grains with transversal diameter higher than two millimeters (grain sieve index, G>2) (Supplementary Table 1). The $\mathrm{N}$ application at different stages did not affect the hectoliter weight and the grain sieve index. In relation to $\mathrm{N}$ levels, the effect was significant only for grain sieve index (Supplementary Table 1). In this study, the cultivar $x$ stage $x$ rate interactions showed significant results for grain sieve index (Supplementary Table 1).

This fact may have occurred because of the higher number of grains per panicle (Table 2), which would increase the competition for photoassimilates in the panicle and consequently reduce the uniform mass of grains. However, thousand-grain weight may be influenced by the stage, where $\mathrm{N}$ is supplied to the plant, where maximum response was obtained with $\mathrm{N}$ made available late (booting) (Table 2). The proportions of split nitrogen fertilization did not affect hectoliter weight (Supplementary material 1). Still, hectoliter weight showed differenced only among cultivars, where the cultivar URS Brava showed the highest average (Supplementary Table 1). This industrial quality parameter has a complex character, which is mainly conditioned by genetic factors, characterizing variation between genotype responses. The grain sieve index $(G>2)$ showed the effect of the $\mathrm{N}$ rate in use (Supplementary Table 1 ), and the data were adjusted to the linear function (Figure 1b). However, these effects were observed for URS Guria cultivar, only due to $\mathrm{N}$ application at stage 31 . A similar trend was found for the protein content of the grains for URS Brava cultivar, only when $\mathrm{N}$ applied at stage 31 (Figure 2c). This fact is supported, since the largest rates of $\mathrm{N}$ keeps photosynthetic activity over a longer time, which may have resulted in 
greater accumulation of reserves in grains, leading to greater size. The cultivars had a significant effect on hectoliter weight and protein content into grains (Supplementary Table 1). Application of $\mathrm{N}$ rate at several stages significantly affected the grain sieve index and crude protein (Supplementary Table 1 ). In this study, the stage $\times$ rate interaction showed significant effects for crude protein (Supplementary Table 1 ). The cultivar $\times$ stage $\times$ rate interactions showed significant results for grain sieve index and crude protein (Supplementary Table 1 ). $\mathrm{N}$ rates and the interaction with cultivar and stage of $\mathrm{N}$ application were effective on protein content into grains (Supplementary material 1). In this way, it should be emphasized that these variables are indicative that the genetic potential of oat genotypes was not limited by $\mathrm{N}$ application, as observed on tables 2 and 3 . There was a single effect of cultivar and rate, double effect of rate versus stage and triple effect on the protein content into grains, indicating an interaction between the cultivars, stages and rates of $\mathrm{N}$ application (Supplementary Table 1). The average crude protein content was $12.4 \%$ (Supplementary Table 1), where cultivar URS Brava showed 13\%; it was higher than that of URS Guria, whose CP content was $11.9 \%$ (Table 3). The maximum contents of protein in the grain were found with the application of $\mathrm{N}$ in a single application during booting (Figure $2 \mathrm{~b})$. The high protein content with the application of $\mathrm{N}$ in these stages is possibly due to the availability of $\mathrm{N}$ in stages closer to grain filling (booting), allowing larger quantities of protein to be synthesized. A large part of the $\mathrm{N}$ used to synthesize proteins in the grain is absorbed prior to flowering. Therefore, it can be inferred that the quantity of $\mathrm{N}$ stored in plant tissues at the time of flowering is what defines the protein contents into grains. The simple effect of $\mathrm{N}$ rates had a positive influence on the protein content of the grains, because it fits to a growing linear function (Figure 2a). However, when the different rates were evaluated at different stages, they significantly influenced the protein content quadratically and only when $\mathrm{N}$ is made available in a single rate at booting, with maximum point of $13.6 \%$ of $\mathrm{CP}$, achieved with the estimate of $65.3 \mathrm{~kg} \mathrm{~N} \mathrm{ha}^{-1}$ (Figure $2 \mathrm{~b}$ ). For crude protein, the interaction of cultivar $\times$ stage $\times$ rate, only showed a significant regression for cultivar URS Brava, with nitrogen fertilization in the first detectable node stage (stage 31; Figure 2c). The function was fitted linearly, resulting in an increase of protein content as a function of $\mathrm{N}$ rate. These results allow making relevant inferences regarding the management of $\mathrm{N}$ to improve the nutritional quality of white oat grains, contributing to the growing demand for research in the area of plant management. Also, the Brazilian Oat Production Guidelines must take into consideration that there is still no knowledge of field experimental results addressing late $\mathrm{N}$ topdressing fertilization in the southern region. Therefore, these results are unprecedented and point to new insight on nitrogen fertilization (topdressing) in oats. Based on these results, it can be inferred that the nutritional quality of white oats grains, about protein content, increases with the availability of $\mathrm{N}$, but it depends on the time of availability of nutrients to the plant and the cultivar being used.

\section{Discussion}

The positive relationship was observed between $\mathrm{N}$ and plant height, especially at stages that plant uses $\mathrm{N}$ for internode elongation. There are reports that $\mathrm{N}$ topdressing from 60 $120 \mathrm{~kg} \mathrm{ha}^{-1}$ (Irfan et al., 2016) or at $30-90 \mathrm{~kg} \mathrm{ha}^{-1}$ of $\mathrm{N}$ (Hawerroth et al., 2015) under high $\mathrm{N}$ fertilization lead to highest plant height.

According to the technical recommendations for oats (2014), cultivar URS Guria is classified as susceptible and URS Brava as moderately susceptible, illustrating the findings. We observed that $\mathrm{N}$ application also interferes the lodging, with significant differences between times of application. This phenomenon was observed for the treatments with $\mathrm{N}$ applied at stages first detectable node and first detectable node + booting of both cultivars. In a recent study, Espindula et al. (2010) found differences between cultivars, stages and nitrogen rates in wheat plants, where the cultivar BRS 210 showed no lodging in any of the forms of application and nitrogen rates. On the other hand, the split application promoted greater lodging than the single-rate application in cultivar TBIO Pioneiro. This shows that the supply of $\mathrm{N}$ to white oats plants plays important role in stage next to first visible node because yield potential is being established. Production components are determined sequentially during crop development, and the beginning of elongation (Zadoks stages 31 to 33) are crucial to define the number of spikelets, the number of grains during the milk development period (Zadoks stages 60 to 75 ) and the size of grains between anthesis and physiological maturity (Zadoks stages 69 to 89 (Maral et al., 2013). These results corroborate with those of Mundstock and Bredmeyer (2001), who with their findings, concluded that oats plants require high availability of $\mathrm{N}$ at the beginning of the cycle, with visible effects on grain yield. In China, Ning et al. (2012) evaluated a hybrid of corn kept with nitrogen levels at 150 and $300 \mathrm{~kg} \mathrm{ha}^{-1}$, applied in the form of urea twice (one third was used as fertilizer and two thirds were applied in the pre-tasseling stage). The authors found no significant differences in grain yield in the treatment they used. The studies conducted with white oats indicate a trend for increase of productivity as the $\mathrm{N}$ rate increased, as observed by Kolchinski and Schuch (2003) and Finnan et al. (2019). However, it should be emphasized that the results indicate the response of plants to nitrogen depends on environmental conditions and genotype tested. Similar data were found by Stefen et al. (2014). They reported an increase in thousand-grain weight with application of $\mathrm{N}\left(30 \mathrm{~kg} \mathrm{ha}^{-1}\right)$ at the reproductive stage of the wheat cultivar Mirante. Benin et al. (2012) evaluated the effect of rates and time of nitrogen application on maize and found significance only for time of $\mathrm{N}$ application. They associated the higher values with the supply of the nutrient, especially in treatments that involved topdressing application, because of the higher leaf content of $\mathrm{N}$ in these treatments. Thousand-grain weight is an important parameter because higher grain yields can be achieved from the same number of embryos, only with the increase in reserves accumulated in the grain depends on up or bottom position of oat panicle (Mut et al., 2018). Uarrota et al. (2017a), studied 21 white oat cultivars, with and without application of fungicide and found differences between URS Guria and URS Brava for important industrial traits, like thousand grain weight, sieve grain index and hectoliter weight. According to Schulz et al. (2013) grain production in different wheat genotypes depends on the adjustment of yield components, number of tillers per plant, number of grains per spike and grain weight. 
Table 1. Chemical properties of the soil used in the experiment. Lages, 2014 growing season.

\begin{tabular}{|c|c|c|c|c|c|c|c|c|c|c|c|}
\hline \multirow{2}{*}{$\begin{array}{l}\text { Mehlich } \\
\text { Soil depth }\end{array}$} & & \multirow{3}{*}{$\begin{array}{l}\text { (\%) } \\
\text { OM }\end{array}$} & \multirow{3}{*}{$\begin{array}{l}\left(\mathrm{mg} \cdot \mathrm{dm}^{-3}\right) \\
\mathrm{P}\end{array}$} & \multirow{3}{*}{$\begin{array}{l}\left(\mathrm{mg} \cdot \mathrm{dm}^{-3}\right) \\
\mathrm{K}\end{array}$} & \multirow{2}{*}{\multicolumn{6}{|c|}{ Sortive complex $\left(\mathrm{cmol}^{\left.\mathrm{d} \mathrm{dm}^{-3}\right)}\right.$}} & \multirow{3}{*}{ V\% } \\
\hline & \multirow{2}{*}{$\begin{array}{l}\mathrm{pH} \\
\mathrm{H}_{2} \mathrm{O}\end{array}$} & & & & & & & & & & \\
\hline$(\mathrm{cm})$ & & & & & $\mathrm{Ca}$ & $\mathrm{Mg}$ & $\mathrm{Al}$ & $\mathrm{H}+\mathrm{Al}$ & SB & CTC & \\
\hline 20 & 5.6 & 4.5 & 5.7 & 159 & 4.04 & 3.66 & 0.00 & 6.90 & 5.6 & 8.11 & 54.01 \\
\hline
\end{tabular}

$\mathrm{PH}=$ potential hydrogenionic; $\mathrm{OM}=$ organic matter; $\mathrm{P}=$ phosphorus, $\mathrm{K}=$ potassium; $\mathrm{Ca}^{2+}=$ calcium; $\mathrm{Mg}^{2+}=$ magnesium; $\mathrm{Al}^{3+}=$ aluminum; $\mathrm{H}+\mathrm{Al}=$ potential acidity; $\mathrm{SB}=$ sum of bases; $\mathrm{CTC}=$ cation exchange capacity; $\mathrm{V} \%=$ base saturation.

(a) $A \times B \times C$ interaction

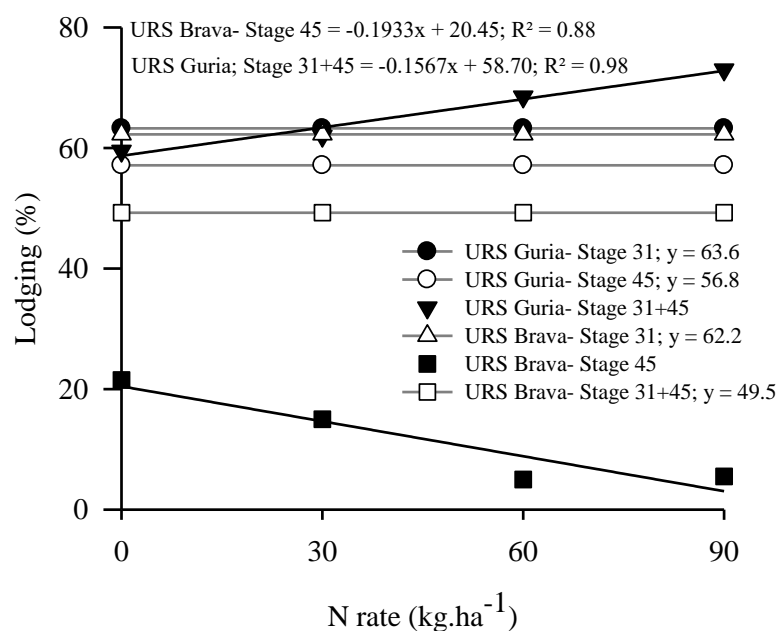

(b) $\mathrm{A} \times \mathrm{B} \times \mathrm{C}$ interaction

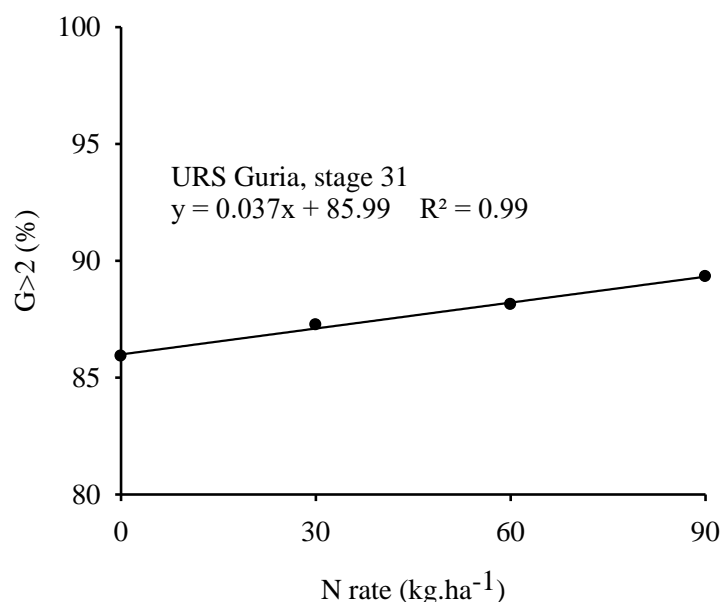

Fig 1. Lodging (a) and grain sieve index $(G>2)(b)$ of white oats cultivars URS Guria and URS Brava grown under four nitrogen rates, applied in a single or split rate at two plant stages. 2014 growing season. ${ }^{*}$ and ${ }^{* *}$, significant at $P<0.05$ and $P<0.01$ by the F-test, respectively; ns- non-significant $(P>0.05)$.

Table 2. Means of lodging (LOD), grain yield (GY), thousand-grain weight (TGW) and number of spikelets per panicle (NSP) of white oats cultivars URS Guria and URS Brava, grown under four nitrogen rates, applied in a single or split rate a two plant stages. Lages/SC, 2014 season.

\begin{tabular}{|c|c|c|c|c|}
\hline Stage & $\begin{array}{l}\text { LOD } \\
(\%)\end{array}$ & $\begin{array}{l}\mathrm{GY} \\
\left(\mathrm{kg} \mathrm{ha}^{-1}\right)\end{array}$ & $\begin{array}{l}\text { TGW } \\
\text { (g) }\end{array}$ & $\begin{array}{l}\text { NSP } \\
(n-9)\end{array}$ \\
\hline First node & $62.9 a$ & $3339.0 \mathrm{a}$ & $30.9 \mathrm{ab}$ & $30.5 \mathrm{a}$ \\
\hline Boot & $34.4 \mathrm{~b}$ & $2623.3 \mathrm{~b}$ & $31.2 \mathrm{a}$ & $27.5 \mathrm{~b}$ \\
\hline Split first node+Boot & $57.5 \mathrm{a}$ & 3459.9 a & $29.9 b$ & $31.3 \mathrm{a}$ \\
\hline Mean & 51.6 & 3117.9 & 30.6 & 29.7 \\
\hline
\end{tabular}

Boot - Booting; first node - first node detectable.

Means followed by different letters, in the column, differ statistically among themselves by Duncan's test $(P<0.05)$.

Table 3. Means of hectoliter weight (HW), number of spikelets per panicle (NSP), crude protein in the grains (CP), plant height (H) and lodging (LOD) of white oat cultivars URS Guria and URS Brava, grown under four nitrogen rates, applied in a single or split rate at two plant stages. 2014 growing season.

\begin{tabular}{|c|c|c|c|c|}
\hline Cultivar & Growth stage & $\begin{array}{l}\mathrm{HW} \\
\left(\mathrm{kg} \mathrm{hl}^{-1}\right)\end{array}$ & $\begin{array}{l}\text { NSP } \\
(\mathrm{n}-)\end{array}$ & $\begin{array}{l}\text { CP } \\
(\%) \\
\end{array}$ \\
\hline & first node & $42.9^{\mathrm{ns}}$ & $32.6^{\text {ns }}$ & $11.7^{\mathrm{ns}}$ \\
\hline \multirow[t]{3}{*}{ URS Guria } & Boot & 44.0 & 29.9 & 12.2 \\
\hline & first node+boot & 42.9 & 31.8 & 11.8 \\
\hline & first node & $47.0^{\mathrm{ns}}$ & $28.4^{\mathrm{ns}}$ & $12.1^{\text {ns }}$ \\
\hline \multirow[t]{2}{*}{ URS Brava } & Boot & 48.1 & 25.1 & 13.4 \\
\hline & first node+boot & 49.2 & 30.9 & 13.5 \\
\hline ? URS Guria & & $43.2 \mathrm{~b}$ & $31.4 \mathrm{a}$ & $11.9 \mathrm{~b}$ \\
\hline \multirow[t]{11}{*}{ ] URS Brava } & & $48.1 \mathrm{a}$ & $28.1 \mathrm{~b}$ & $13.0 \mathrm{a}$ \\
\hline & & $\begin{array}{l}\text { URS Guria } \\
\text { Plant height } \\
-\end{array}$ & URS Brava & \\
\hline & first node & A $1.20 a b$ & A $1.23 \mathrm{~b}$ & \\
\hline & Boot & A $1.18 b$ & A 1.17 c & \\
\hline & first node+boot & B $1.22 \mathrm{a}$ & A 1.26 a & \\
\hline & mean & ${ }^{\mathrm{ns}} 1.20$ & 1.22 & \\
\hline & & $\begin{array}{l}\text { URS Guria } \\
\text { Lodging index } \\
-y^{---~(\%) ~----~}\end{array}$ & URS Brava & \\
\hline & first node & A $63.2 \mathrm{ab}$ & A 62.2 a & \\
\hline & Boot & A 57.1 b & B 11.7 c & \\
\hline & first node+boot & A 65.7 a & B 49.2 b & \\
\hline & mean & A 62.0 & B 41.0 & \\
\hline
\end{tabular}


(a) Rate effect

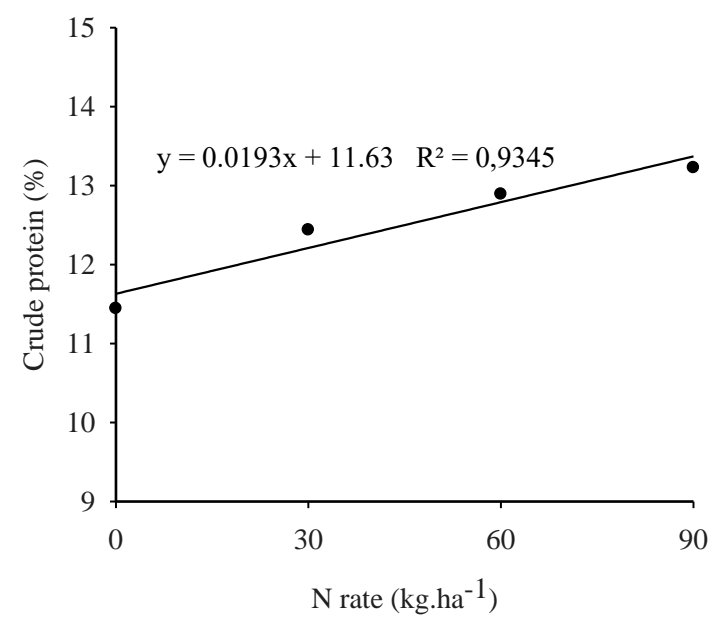

(c) $A \times B \times C$ interaction

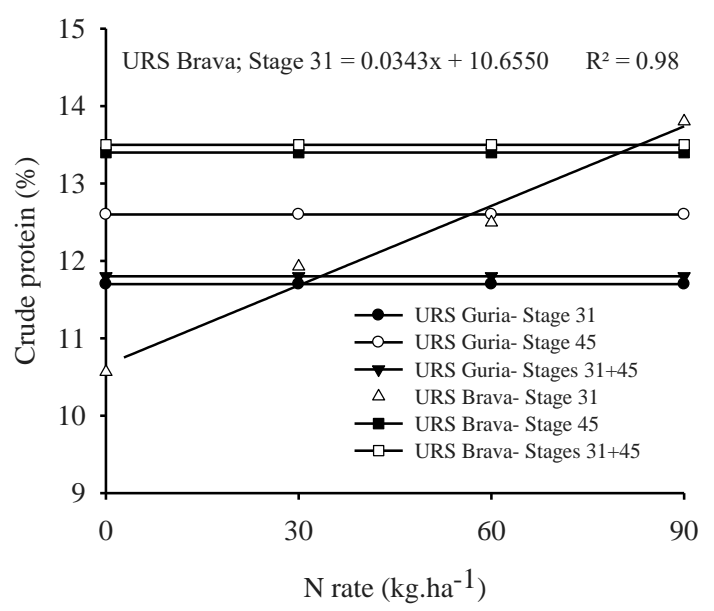

Fig 2. Grain protein of white oats cultivars URS Guria and URS Brava grown under four nitrogen rates applied in a single or split rate at two plant stages: (a) N rate single effect; (b) Single effects of plant stages and (c) N rate, stage and cultivar interactions. 2014 growing season. ${ }^{*}$ and $* *, P<0.05$ and $P<0.01$ significance by the $\mathrm{F}$-test, respectively; ns- non-significant $(P>0.05)$.

Similar results were found by Teixeira Filho et al. (2007) when they evaluated the effect of nitrogen fertilization on the agronomic performance of wheat cultivars. These authors found that hectoliter weight was not significantly affected by the $\mathrm{N}$ rates tested $\left(0 ; 20 ; 30 ; 40 ; 50\right.$ and $60 \mathrm{~kg} \mathrm{ha}{ }^{-}$ $\left.{ }^{1}\right)$, applied at sowing and at the end of tillering. Hectoliter weight is an important parameter in the marketing of oat grains and it is closely related to the proportion of caryopsis and bark (dehulling index). According to Finnan et al. (2019) the hectoliter weight value may increase, if $\mathrm{N}$ is applied at 30-32 plant stage. Also, according to Tavares et al. (2014), hectoliter weight trait varies strongly according to environmental conditions, a fact which may explain the lack of response of cultivars to rates and application times of $\mathrm{N}$ in the plant. Wanser and Mundstock (2007) characterized the period of critical development for $N$ supplementation at topdressing of barley based on the expression of grain yield components. They concluded that the treatment where $\mathrm{N}$ was applied at the beginning of the cycle (emission of the third leaf) stimulated plants to increase the number of spikelets per spike. This observation justifies the result found with the smallest number of spikelets per spike (Table 2 ) by postponing topdress nitrogen fertilization, i.e., only at (b) $\mathrm{B} \times \mathrm{C}$ interaction

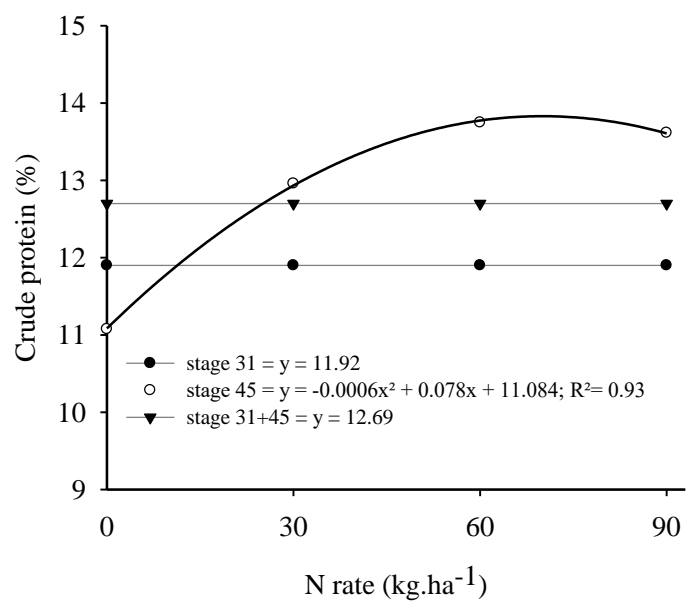


municipality, according to the Köppen scale, is Cfb - humid, subtropical, mesothermal, with the cool summers in winter and spring. There are severe and frequent frosts, with no dry season, with an average annual temperature of $15.7{ }^{\circ} \mathrm{C}$ and average yearly rainfall in the region of $1,556 \mathrm{~mm}$ (Wrege et al., 2012). The experimental area has been cultivated under no-tillage system, and the previous crop was soybean. The soil was collected at the depth of $0.20 \mathrm{~m}$ layer, and the results of the chemical analysis are shown in Table 1.

\section{Plant materials, treatments, conduction of study and experimental design}

The study was developed between July 4th and December 12th, 2014. The mechanized seeding of white oats was performed using 350 viable seeds. $\mathrm{m}^{-2}$. The experiment was carried out in a randomized block, split-plot design, with four replications. The treatments consisted of a combination of factors. The main plots were white oat cultivars (URS Guria and URS Brava. These two cultivars were chosen because (i) URS-Guria, was previously characterized as medium industrial quality (Silveira et al., 2016) and (ii) URS-Brava being new cultivar and potentially contrasting high quality). The sub-plot were three management strategies of $\mathrm{N}$ application (first detectable node-semi-late; booting-late and split $\mathrm{N}$ at first detectable node-semi-late + booting-late, described by Zadoks as stages $31,45,31+45$ ) and sub-subplot were the $\mathrm{N}$ topdressing rates (absence of $\mathrm{N}, 30,60$ and $\left.90 \mathrm{~kg} \mathrm{ha}^{-1}\right)$. The $\mathrm{N}$ was spread in the form of urea. Each experimental sub-sub-plot were composed of 5 rows with 5 meters in length, spacing between rows $0.2 \mathrm{~m}$ resulting in a total area of 5 square meters. In each plot, each external row was discarded on both sides and $0.50 \mathrm{~m}$ was discarded from each end, resulting in $2.4 \mathrm{~m}^{2}$ of useful area per plot. Base fertilization consisted of the application of $400 \mathrm{~kg} \mathrm{ha}^{-1}$ of the 5-20-10 ( $\left.-\mathrm{P}_{2} \mathrm{O}_{5}-\mathrm{K}_{2} \mathrm{O}\right)$ a commercial NPK formulation applied into each row at sowing date. All other white oats managements were as usually applied in conventional cultivation as soon as they were necessary, according to Brazilian technical recommendations for the oat crop (CTBPA, 2014).

\section{Traits measured}

When the plants reached physiological maturity, we evaluated the: (i) plant height $(\mathrm{cm})$ by measures from the stem base (close to the soil level) until the panicle end (most apical spikelet). On this day, (ii) the plant lodging was assessed by visual estimation as a percentage, based on the angle formed in the vertical position of the stem, compared to the ground and the area of lodged plants, as described by Hawerroth et al. (2015). After that, 10 plants were harvested from the central row of each plot for visual evaluating: (iii) the number of spikelets per panicle and (iv) the number of grains per spikelet. The grain harvest was performed with a mechanized form using a plot combine. It occurred when $90 \%$ of the panicles had grains whose color was typical of harvest maturity. After harvest the grains were stored in a cold chamber ( 7 o $C / 60 \%$ relative humidity-RH) for 10 days until the further analyses started. The following evaluations were performed as our previous work (Uarrota et al., 2017b): (v) degree of moisture, determined by the oven method at $105{ }^{\circ} \mathrm{C}$ for 24 hours; (vi) grain yield: determined on the basis of the production of the each plot, by correcting the water content by moisture presented in each plot at the default value of $13 \%$; (vii) thousand-grain weight: determined by counting the number of grains present in a sample of 5g; (viii) hectoliter weight: measured from a sample of grains, which was inserted into a tube with known volume of $0.25 \mathrm{~L}$ (Dalle Molle hectoliter weight balance, type 40); after that, such grain weight was measured; (ix) dehulling rate: determined by weighing $2 \mathrm{~g}$ of grains (glumes + caryopsis) which were individually and manually dehulled and weighed again, thus determining caryopsis weight; $(x)$ percentage of grains with transversal diameter higher than two millimeters (grain sieve index, $\mathrm{G}>2$ ): determined by weighing and later sifting a sample of $250 \mathrm{~g}$ of grains, in a rectangular sieve whose holes were $2 \mathrm{~mm} \times 20 \mathrm{~mm}$; then, the sample was weighed again. (xi) Total protein content was determined from the total nitrogen content in the sample, where protein percentage is equal to nitrogen content $x$ 6.25. Nitrogen concentration was determined using the Kjeldahl method, described by Prazeres and Coelho (2016).

\section{Statistical analysis}

The data were subjected to analysis of variance by the F-test and, when significant variations were detected, the means were compared by Duncan's test at $5 \%$ probability of error. For the traits presented as percentage, the data were transformed by $(x+0.5)^{1 / 2}$ with the aim of normalizing the distribution of errors. For the quantitative factors, adjustment of regression was performed. Among the tested functions for data adjustment, a choice was made for models whose components of the equation were significant at $5 \%$ probability.

\section{Conclusion}

Oats cultivars, $\mathrm{N}$ levels and stages affect the plant height, lodging, thickness and protein content of the grains. Semilate $\mathrm{N}$ application increases plant height and its lodging indices, but it is important for highest yield components and grain yield. Split topdressing fertilization in two applications of $\mathrm{N}$, like $50 \%$ at the beginning of stem elongation and $50 \%$ at booting, favored higher yield, higher industrial quality and higher protein content into grains. Only late $\mathrm{N}$ application (booting stage) increases grain protein but decrease grain yield. The increase in $\mathrm{N}$ rates up to $90 \mathrm{~kg} \mathrm{ha}^{-1}$ provided increased thickness and protein content of the grains in white oats cultivars, thus increasing nutritional and industrial quality and showing to be a potential management practice, even if it has not increased grain yield. The results showed more protein per $\mathrm{g}$ of grain are important to consumer; more flakes per ton of grains are important to industry and the increase on grain yield lead to more profit to farmer.

\section{Acknowledgements}

The authors would like to thank CNPq, CAPES, FAPESC/UDESC/PAP and UNIEDU for their financial support to the present research and the scholarships granted to the authors.

\section{References}

Ayadi S, Karmous C, Chamekh Z, Hammami Z, Baraket M, Esposito S, Rezgui S, Trifa Y (2016). Effects of nitrogen rates on grain yield and nitrogen agronomic efficiency of durum wheat genotypes under different environments. Ann Appl Biol. 168(2): 264-273. 
Benin G, Bornhofen E, Beche E, Paglioss, ES, Silva CL, Pinnow C (2012) Agronomic performance of wheat cultivars in response to nitrogen fertilization levels. Acta Sci, Agron. 34(3): 275-283.

Companhia Nacional de Abastecimento CONAB (2019) Acompanhamento da safra de grãos Brasileira: Nono levantamento, junho 2019 - safra 2018/19. Brasília: Companhia Nacional de Abastecimento. 2016. Retrieved August, 2019, from https://www.conab.gov.br/infoagro/safras/graos/boletim-da-safra-degraos/item/download/28059 aa1796452a062bb311354e7f32 e7e664

CTBPA. Comissão Brasileira de Pesquisa da Aveia. (2014). Indicações técnicas para a cultura da aveia. 2a ed. A Comissão e Fundação $A B C$, Passo Fundo (RS), Brazil. Retrieved September, 2018, from http://editora.upf.br/images/ebook/cultura aveia.pdf

Ernani PR (2016) Química do solo e disponibilidade de nutrientes. Graphel, Lages. Brazil

Espindula MC, Rocha VS, de Souza MA, Grossi J.AS, de Souza LT (2010) Nitrogen application methods and doses in the development and yield of wheat. Ciênc Agrotec. 34(6) 14041411.

Finnan JM, Spink J (2017) Identification of yield limiting phenological phases of oats to improve crop management. J Agric Sci. 155(1): 1-17.

Finnan J, Burke B, Spink J (2019) The effect of nitrogen timing and rate on radiation interception, grain yield and grain quality in autumn sown oats. Field Crops Res. 231(1): 130-140.

Güler M (2011) Nitrogen and irrigation effects on grain $\beta$-glucan content of oats (Avena sativa L.) Aust J Crop Sci. 5(3):242-247.

Hartwig I, de Oliveira AC, de Carvalho FFI, Bertan I, da Silva JAG, Schmidt DAM, Valério IP, Maia LC, Fonseca DAR, dos Reis CES (2007) Associated mechanisms of aluminum tolerance in plants. Semina: Ciênc Agrár. 28(2) 219-228.

Hawerroth MC, da Silva JAG, Souza CA, de Oliveira AC, Luche HS, Zimmer CM, Hawerroth FJ, Schiavo J, Sponchiado JC (2015) Lodging reduction in white oat using the plant growth regulator trinexapac-ethyl. Pesq Agropec Bras. 50(2): 115-125.

Hooda S, Matte JJ, Vasanthan T, Zijlstra RT (2010) Dietary oat $\beta$ glucan reduces peak net glucose flux and insulin production and modulates plasma incretin in portal-vein catheterized grower pigs. J Nutr. 140(9): 1564-1569.

Irfan M, Ansar M, Sher A, Wasaya A, Sattar A (2016) Improving forage yield and morphology of oat varieties through various row spacing and nitrogen application. The J Anim Plant Sci. 26(6): 1718-1724.

Jones MB, Finnan J, Hodkinson TR (2015) Morphological and physiological traits for higher biomass production in perennial rhizomatous grasses grown on marginal land. GCB Bioenergy. 7(2): 375-385

Kolchinski EM, Schuch LOB (2002) Grain yield and nitrogen utilization in oats in relation to nitrogen fertilization timing. $\mathrm{R}$ Bras Agrociência. 8(2): 117-121.

Lin $Y C$, Hu YG, Ren $C Z$, Guo $L C$, Wang $C L$, Jiang $Y$, Wang $X J$, Hlatshwayo P, Zeng ZH (2013) Effects of nitrogen application on chlorophyll fluorescence parameters and leaf gas exchange in naked oat. J Integr Agric. 12(12): 2164-2171.

Mingotte FLC, Gonçalves MHG, Yada MM, Fornasieri Filho D, Lemos LB (2015) Agronomic efficiency and grain quality of upland rice cultivars as a function of nitrogen topdressing. Biosci J. 31(3): 748-758.

Maral H, Dumlupinar Z, Dokuyucu T, Akkya A (2013) Response of six oat (Avena sativa L.) cultivars to nitrogen fertilization for agronomical traits. Turk J Field Crops 18(2): 254-259.

Mundstock CM, Bredemeier C (2001) Nitrogen availability and its relation with oat tillering and grain yield. Ciênc Rural. 31(2): 205-211.
Mut Z, Erbas OD, Akay H (2018) Variation of some physical and chemical quality traits of the grains in different parts of the oat panicle. Int J Agric Biol. 20(2): 268-276

Nelson KA, Motavalli PP, Smoot RL (2009) Utility of dried distillers grain as a fertilizer source for corn. J Agric Sci. 1(1): 312.

Ning T, Zheng Y, Han H, Jiang G, Li Z (2012) Nitrogen uptake, biomass yield and quality of intercropped spring-and summersown maize at different nitrogen levels in the North China Plain. Biom Bioenergy. 47(1): 91-98.

Oliveira AC, Crestani M, de Carvalho FIF, da Silva JAG, Valério I P, Hartwig I, Benin G, Schmidt DAM, Bertan I (2011) Brisasul: a new high-yielding white oat cultivar with reduced lodging. Crop Breed Appl Biotechnol. 11(4): 370-374.

Prazeres CS, Coelho CMM (2016) Genetic divergence and heterosis related to physiological quality in maize seeds. Bragantia, 75(4): 411-417.

Rial-Lovera KP, Davies WP, Cannon ND, Conway JS (2016) Influence of tillage systems and nitrogen management on grain yield, grain protein and nitrogen-use efficiency in UK spring wheat. J Agric Sci. 97(8): 1-16.

Silveira SFS, Oliveira DCS, Wolter DD, Luche HS, Oliveira VF, Figueiredo RG, Stulp C, Carbonari H, Hawerroth MC, Gutkoski LC, Maia LC, Oliveira AC (2016) Performance of white oat cultivars for grain chemical content. Can J Plant Sci. 96(4): 530-538.

Stefen DLV, Souza CA, Coelho CMM, Tormen ME, Zanesco PR, Casa RT, Sangoi L, Nunes FR (2014) Nitrogen management associated with growth retardants in wheat cv. Mirante. Rev Ciênc Agrovet. 13(1): 30-39.

Schulz R, Makary T, Hubert S, Hartung K, Gruber S, Donath S, Dohler J, Weiss K, Ehrhart E, Claupein W (2015) Is it necessary to split nitrogen fertilization for winter wheat? On-farm research on Luvisols in South-West Germany. J Agric Sci. 153(4): 575-587.

Tavares LCV, Foloni JSS, Bassoi MC, Prete CEC (2014) Wheat genotypes under different seeding rates. Pesq Agropec Trop. 44(2): 166-174.

Teixeira Filho MCM, Buzetti S, Alvarez RCF, de Freitas JG, Arf O de Sá ME (2007) Response of wheat cultivars irrigated by sprinkler to side dressing nitrogen under savannah soil. Acta Sci. Agron. 29(3): 421-425.

Uarrota VG, Souza CA, Sponchiado JC, Coelho CMM (2017a) Assessment of yield attributes and industrial quality parameters of oat cultivars (Avena sativa L.) using multivariate techniques (PCA, PLS-DA and OLS-R). J Exper Agric Internat. 17(4): 1-13

Uarrota VG, Coelho CMM, Sponchiado JC, Souza CA (2017b) Discriminating important agronomic and industrial parameters of white oat cultivars treated with fungicide based on SIMCA algorithm. J Agric Sci Tech B. 7(2): 86-99.

Wamser AF, Mundstock CM (2007) Nitrogen fertilization at different growth stages in barley, cultivar 'MN 698'. Ciênc Rural 37(4): 942-948.

Webster F, Wood PJ (2011), Oats - Chemistry and Technology. 2nd Edition; eBook ISBN: 9780128104521.

Wrege MS, Steinmetz S, Reisser Júnior C, de Almeida IR (2012) Atlas climático da Região Sul do Brasil: Estados do Paraná, Santa Catarina e Rio Grande do Sul. Pelotas: Embrapa Clima Temperado; Colombo: Embrapa Florestas, Brazil. Retrieved September, 2018, from https://www.embrapa.br/busca-depublicacoes/-/publicacao/1045852/atlas-climatico-da-regiaosul-do-brasil-estados-do-parana-santa-catarina-e-rio-grandedo-sul

Zadoks JC, Chang TT, Konzak CF (1974) A decimal code for the growth stages of cereals. Weed Res. 14(6): 415-421. 